\title{
A study on the risk of the direct investment of Yunnan enterprises in India
}

\author{
Yu Liu* \\ International Business School \\ Yunnan University of Finance and Economics \\ Kunming, China \\ liuyu_913@outlook.com \\ Hong Yi \\ International Business School \\ Yunnan University of Finance and Economics \\ Kunming, China \\ ynyihong@126.com
}

\author{
Wen Zhang \\ International Business School \\ Yunnan University of Finance and Economics \\ Kunming, China \\ zhangxiaowen615@163.com
}

Wei Wang

International Business School

Yunnan University of Finance and Economics

Kunming, China

704234551@qq.com

\begin{abstract}
In recent years, the Chinese government has accelerated the pace of "going out", and has pushed Chinese enterprises to do foreign direct investment. But foreign direct investment has the characteristics of high risk, which contains the general risk of investment decision-making, and the risk of business production and operation. In addition, it also be faced with many uncontrolled risks after carrying out investment activities abroad, such as the changes of exchange rate, national political risk and so on. In the process, enterprises of Yunnan that have less activities in the field of international production and operation, will encounter a series of problems and difficulties. However, it is an important aspect for China to promote enterprise foreign direct investment vigorously in the new period. Therefore, the correct understanding of various risks that Yunnan enterprise maybe faced in foreign direct investment is the core problem at the present stage. And the management of the investment risk is especially critical.
\end{abstract}

Keywords-going out; foreign direct investment; Investment decisions

\section{INTRODUCTION}

In recent years, with the smooth implementation of Chinese "going out" strategy, the number of foreign projects and personnel continues to increase. Continued growth of our country's foreign direct investment has become the new icon for the "rise of China". And it has played a significant role in promoting competitiveness and development of Chinese enterprises. But due to the lack of the intricacies of the environment in the international management of Chinese enterprise and the management level is relatively low, overseas direct investment activities of Chinese enterprises are faced with many risks, and enterprises had suffered irreparable loss. In the past, the research on the risk of Chinese enterprises' foreign direct investment mainly focuses on the general characteristics of the foreign direct investment risk, which has not considered the present situation of Yunnan enterprises, but also has not considered the regional background of India. Therefore, under the background of the complex environment in India, how to prevent the risk of foreign direct investment enterprises has become the problem that needs to be solved urgently. In this paper, to study the risk of foreign direct investment in Yunnan enterprises, hoping to provide a little reference and useful inspiration for direct investment activities of Yunnan enterprises in India.

\section{A. Current research situation in foreign countries}

There are many researches of foreign direct investment risk abroad. Beck's Risk Society Theory discusses the causes of risk in society and the issue of risk prevention, and now it has become one of the classical theory tools for western countries to make comprehensive analysis of contemporary social macro-environment and to make decision-making and investment planning for enterprises. What's more, it will give Chinese enterprises important implications for the interpretation of the source of risk that China's enterprises are facing with, the nature of the risks and how to manage it. The risk management theory of foreign direct investment is more concerned with the risk of foreign direct investment caused by the problem of mechanism, and then provides a more fundamental solution to the risk management. From the view of the phenomenon and the issue, the theory of risk management of foreign direct investment makes comb mainly from the macro perspective, the government regulation and the enterprise management, and so on. Theory of foreign direct investment in risk management puts forward the endogenous risk in the process of foreign direct investment based on the perspective of corporate governance structure. From the perspective of government regulation, the risk management theory of foreign direct investment is based on the study of foreign governance model and mechanism, and puts forward the policy guidance on the national level of risk control of foreign direct investment in China.

\footnotetext{
* Corresponding author
} 


\section{B. Domestic Research Situation}

Wang Yuanlong suggested that the economic benefits has decisive significance for China's foreign direct investment behavior, then put forward the economic interests of transnational investment decision theory. Economic benefits decision theory and its later development does not propose specific measures to address the risk management of firmspecific situation, but has laid a good theoretical basis for the later development of the theory of risk control system and provides a concise thinking framework and the internal logic for risk control in the perfection of theoretical system. Development Strategy Theory was proposed by the Chinese scholars Qiao Huiping, he described the strategic objectives of the development strategy, the main strategy, location strategy, business strategy, and strategic manner. It makes our multinational rational to follow in the process of foreign direct investment, to prevent unnecessary losses in time, to improve the overall efficiency of enterprises, and to strive for the highest level of profits. The development strategy theory is the main theory system of the overseas direct investment theory and risk management theory of our country, and it has been the focus of the research on the theory of transnational investment in China

The above research experience at home and abroad provides valuable experience for Yunnan enterprises in the risk of direct investment in India.

\section{THE OVERVIEW OF RISKS IN FOREIGN DIRECT INVESTMENT}

\section{A. The connotation of foreign direct investment risk}

Risk is the possibility of some uncertainty in the event of possible future losses on the assets and earnings or promote additional revenue. Risk actually has dual possibility of gain and loss. In the activities of foreign direct investment, the uncertainty of the event will be more which will has an impact on earnings of foreign direct investment. In general, the possibility of loss of income due to the uncertainty of the foreign direct investment is called the risk of foreign direct investment. Compared with domestic investment, the risks of international direct investment are far greater than the risks of domestic investment, due to the different national economic system, political system, economic policy, fluctuations of interest rate and exchange rate appear in the process of investment and management of currencies, investments with selection bias and the influence of factors such as the complexity of the investment management,. Compared with indirect investment, the assets formed by direct investment may become land, housing, machinery, equipment and other tangible assets and technology, trademarks and other intangible assets, most of the assets liquidity is poor. As a result, foreign direct investment is more risky than indirect investment.

\section{B. Types of foreign direct investment risks}

\section{1) Political risk}

Political risk refers to the changes of the political situation of the host country, which leads to the changes of the investment environment, so as to cause the loss of the investment activities for foreign investors. Generally speaking, the political risk is mainly caused by the changes of the host country's political situation and the war, the host country's protectionism policy and so on.

\section{2) Economic risk}

Each country has its economic cycle, in times of economic upswing, it has smooth product sales, and factory production is at full capacity, and profits is increased. Once it enters the low tide period, product sales are sluggish, factories are running below capacity, but the fixed costs will not be reduced. Sales revenue decreased and the cost of unit product increased lead to the decrease of enterprises' net income.

\section{3) Business risk}

Management risk is the possibility that investors cannot get the normal profits due to errors of overseas enterprises in decision-making in production and management. Due to the differences of cultural environment, customs, language, decision information are often not sufficient for overseas enterprises management personnel. Even some wrong information will be brought into the decision-making process, it will lead to policy mistakes and losses to the business.

\section{DIRECT INVESTMENT RISK ANALYSIS OF YUNNAN ENTERPRISES IN INDIA}

\section{A. Direct investment environment risk of Yunnan enterprises in India}

India's weak infrastructure is already known around the world, including the area of power, transportation and communications. According to the Global Competitiveness Index published by the World Economic Forum, India's infrastructure ranked 91st place in 139 countries; In 2009, McKinsey \& company released a report that infrastructure lag can lead to economic growth in India in 2017 fell 1.1 percentage points, is expected to bring India economic losses up to $\$ 200$ billion.

Due to the existence of the investment environment is not perfect and many other issues, foreign investors' plan in India is difficult to promote. Even if the investment projects has completed or put into operation, but also it will encounter endless trouble. In general, the Indian government's approval of foreign investment projects is inefficient, corruption is serious. And if you need land acquisition, it often leads to some serious disputes. In terms of investment environment, infrastructure and human resources has serious shortcomings and gaps. In addition, there are potential nationalism and populist political impact in India.

India has proposed that it would spend \$ 1 trillion to build infrastructure in the next few years, attracting foreign investment is one of the main means of financing. From the development experience of the world, using foreign investment to develop the country's infrastructure is in line with India's international interests. On the basis of existing achievements, Chinese government departments and enterprises hope to significantly enhance the level and scale of cooperation in infrastructure construction between China and India: China and India held the second strategic economic dialogue in November 
2, 2012, the two sides decided to set up a working group on infrastructure to promote bilateral cooperation in railway construction; March 18, 2014, China and India held the third strategic economic dialogue, the two sides agreed to continue to improve the investment and business environment and encourage the two enterprises to expand mutual investment between the two countries, strengthen infrastructure, energy saving and environmental protection, information technology, energy and financial cooperation, and more inclined to the people's livelihood, to better promote the sustainable economic development of the two countries and benefit the two peoples.

Deep cooperation programs between China and India in the field of investment, economic and trade has aroused great concern in the world. For many Yunnan enterprises, which are actively implement the "going out" strategy, urgently need to develop overseas business to gain a competitive advantage in South Asia and Southeast Asia, the huge business opportunities must not be ignored. The experience of history tells us that we must strictly and comprehensively analyze the risks of their existence when any business opportunities appear, and should propose coping strategies. Only in this way can we base on the invincible position.

\section{B. Direct investment Political risk of Yunnan enterprises in India}

First, the construction project in India is faced with problems of cumbersome control and bureaucracy. As of the beginning of this year, Heilongjiang Longjian Road \& Bridge Company has built 143 kilometers highway and 21 bridges totally in India. Although the company belongs to one of the participating companies named by India, it is still mired in Indian bureaucracy. For example, the company wanted to build an asphalt concrete mixing station in the state of Haryana site, it actually needed to be signed 29 times from 14 people. Due to the environmental protection procedures was involved, the chief minister must signed, too. It took 6 months to run all the procedures.

Second, India's education structure is not perfect, there is a huge gap in basic education, forming the largest illiterate population in the world, and the level of individual institutions of higher education and research failed to make up for this deficiency. For a country to develop modern manufacturing, it is impossible to rely solely on a handful of elite force that can accomplish.

Third, in terms of railway infrastructure, there are also huge risks in operation management. The history of India railway is relatively long, but the level of operation and management is very low, once appeared the anecdote in the history that hundreds of kilometers of train travel were in the wrong direction. India's National Crime Bureau of Statistics' 2011 annual report on suicide and accidental deaths in India, said that the death toll of the railway accident in 2010 for 27798 people, 28238 people in 2011. In this level of management, once the introduction of China's high-speed rail accident appears in India, the public is very easy to blame the Chinese enterprises.

Fourth, the characteristics of Indian democracy is decision repeatedly and corruption seriously, economic environment with high degree of uncertainty. Risks that the less liquidity of direct investment faces are greater and more serious than the high liquidity portfolio does. In the history of India, direct investment agreements signed by the previous government were overthrown by successor governments under the pretext of "people's livelihood", "anti-corruption", such phenomenon is not uncommon. In the 1990s the new government of Maharashtra overthrow the power plant contract signed between the former government and American Enron Company, on the grounds that the price is too high which beyond the bear ability of people. Over a long period of time, India's electricity, railway, gas infrastructure and basic industry development lags behind, one of the important reasons is that government's subsidies are so high that these industries had almost lost industry self-development, technical ability to improve itself. And it also makes a direct threat to the stability of the country's fiscal and balance of payments.

As a result of the Indian government insufficient financial resources, huge fiscal deficits, China cannot implement some important infrastructure projects at the low risk model of "India funded, China contracted". The only viable way that Chinese investors use in a large part of the project implementation is BOT construction and operation. After the expiry, Chinese investors should transfer it to the government of India. Uncertainty of this model is much higher: In India's current infrastructure pricing system, Chinese investors' implementation of BOT mostly only harvest losses; And to formulate implementation for Chinese BOT project in accordance with market price standard, it will also faces the uncertainty risks of government transition.

\section{Land disputes risk of direct investment of Yunnan enterprises in India}

Land dispute is one of the largest political risk of investment and construction sectors of Yunnan enterprises in India, as well as a knot, once caught, it is most difficult for India to schedule the execution of the contract. And enterprises will be dragged down, it is difficult to play a consistent and efficient advantage.

The origin of the land dispute can be said to the Indian private ownership of land. In the use of farmlands in the process, cost bearer and winner of the compensation is often not the same body in India. Leasing land tenant farmers and small farmers with small amounts of land to bear most of the cost and risks, landowners who own large tracts of farmland and do not work in person have received most of the compensation. Once the tenant farmers and small farmers lose their land, they lost their means of livelihood and basic security. The India government's efficiency is low and cannot come to pay compensation to farmers, so that farmers lose their trust in government. Indian manufacturing industry is underdeveloped, and has less employment opportunities. Farmers are affected by low levels of education, it is difficult to finish the project according to plan, and it also make the farmers unable to employment, even basic living has become a problem. However, for India landlord, the huge land acquisition compensation is far greater than the relatively small land rent. Therefore, in many land disputes, no matter how violent the protests and resistance are, the land acquisition program can 
still continue. In order to improve their land acquisition compensation, landlords often look forward to the outbreak of the land dispute, and even take the initiative to provoke disputes. Because as long as a protest, land prices will rise exponentially, the landlord can get huge economic benefits, and win political support in the vast majority of the rural population. This mode of privatization of benefits and socialization of costs must intensify the social contradiction.

In densely populated developing countries in Asia, providing employment opportunities in the non-farm sector is the key to solve the disputes of land expropriation. And a more critical solution is to vigorously develop the manufacturing industry, this is because to achieve a certain population scale economies and regional speaking, only a solid manufacturing base to a country can provide stable and a lot of income and employment opportunities and ensure the sustainable economic growth and social stability. However, due to historical reasons, the development of manufacturing sector is lagging in India, the transfer of labor is limited by the reality of underdeveloped manufacturing. Due to the low level of education, the land lost farmers cannot adapt to the more complex work opportunities because of their ability to work and professional quality. Therefore, farmers cannot directly go across to the service industry employment because of a lack of employment opportunities in manufacturing industry. Manufacturing processing industry is still the key sector to solve the employment of landless peasants. Thus, India faces difficult to solve "urbanized" landless peasants livelihood, and get into the vicious cycle of "manufacturing underdeveloped - cannot provide employment compensation - difficult land acquisition difficult to develop the manufacturing sector - jobs not grow".

For Yunnan investors, such Indian land dispute deadlock are daunting challenges. In addition, the international situation in India is determined to the phenomenon that India elite class will fall into the competition with China. Once the land acquisition dispute happens, it is very easy to blame the situation to the Yunnan enterprises.

\section{SugGeStions ON THE RISK OF DiRECT INVESTMENT OF YUNNAN ENTERPRISES IN INDIA}

With the enhancement of China's national comprehensive strength, the intensity of foreign direct investment enterprises in Yunnan Province continues to increase. However, foreign direct investment of Yunnan still exists many problems due to the influence and constraints of various factors. For example, the scale of foreign investment is small, lacks scientific strategic planning, lacks government guidance and supervision, lacks high-quality professional personnel, and the financial service system is not perfect and so on. Therefore, Yunnan enterprises must take a targeted risk response strategy as soon as possible, in order to allow the foreign direct investment of Yunnan enterprises to receive a good effect effectively.

Apart from measures to response to the risks, measures to prevent and resolve the risks of Yunnan enterprises in the process of direct investment in India is also particularly important. Firstly, the establishment of finance risk management mechanism is important. Foreign direct investment enterprises should flexibly use various financing channels and financial instruments to reduce financing risks. In particular, if foreign enterprises need short-term liquidity, they should seek local solutions in India as far as possible. You can avoid the effects of changes in exchange rates from the way of local finance, local using, local payment of principal and interest and using the same currency. In addition, you should adhere to borrow hard currency, pay back soft money, make collocation of soft and hard currency with a reasonable principle in order to reduce or avoid the risk of foreign exchange losses. Secondly, it is indispensable to establish a comprehensive regulatory organization system. On the one hand, for the current situation of management confusion, the proposed establishment of specialized overseas investment management institutions to strengthen the macro management of foreign direct investment is one of the most useful measurement. On the other hand, we should take actions to establish the overseas investment audit and performance evaluation mechanism. The purpose of establishing a separate audit and performance evaluation organization is to separate the approval and audit functions in order to facilitate mutual restraint. Thirdly, we should strengthen the construction of the regulatory system. To strengthen the legal system in foreign direct investment, we should make a comprehensive basic law to protect, encourage and manage the overseas direct investment as soon as possible. The law should regulate the government administrative privileges on all kinds of overseas direct investment and investment main body of rights and obligations. The law should also show the basic attitude of the government to the investment overseas and should lists the incentive and restriction measures. On this basis, we should also summarize the practical experience in a timely manner, with the purpose of planning, develop other supporting regulations step by step according to the demands. In the formulation of these laws and regulations, we should realize the feasibility of implementation and make it combined with the actual needs.

Yunnan enterprises in India to carry out large-scale projects and infrastructure cooperation is an effective way to achieve a win-win cooperation, but there are many risks and challenges. Under these circumstances, we must be careful of decisionmaking, proper arrangements. Yunnan enterprises should make adequate analysis of the potential risks from multiple layers, and make proper arrangements for introduction of categories of Chinese technology, management, as well as Chinese workers in the various segments if they want to invest in India. Yunnan enterprises should introduce appropriate technology according to India's actual management level and demand, rather than pursuing the most advanced technology blindly. It is very important for Yunnan enterprises to avoid full of unnecessary political risks for the land expropriation disputes link. In the investment cooperation, the two sides should clear the respective responsibilities of the division of labor in the management and other aspects, allow China to be able to get rid of India's domestic political problems, and take attention to play technology that we are good at and to construct our own commercial operational advantages. All of these measures can make it easier to cooperate, and make India nationals enjoy the improved investment environment and the benefits of better infrastructure successfully. 


\section{ACKNOWLEDGEMENT}

As I finished this paper, I am really willing to give my sincere gratitude to those who have kept giving me so much help. First,I would like to thank my supervisor Professor Yi Hong with all my heart. Without his constant encouragement and guidance, I would not finish this paper. Second, my good wishes to all the teachers in International Business School, they have given me professional knowledge. Third, my special thanks to my classmates and my friends who have prepared to give me a hand whenever I need.

\section{REFERENCES}

[1] L.R. Li, "Analysis on the legal environment of Chinese enterprises inves ting in coal industry in India," India Ocean Economy Research, vol. 2, 2 014, pp.106-120.
[2] M.X. Shen, "China's current situation and prospect of investment cooperation in India," International Economic Cooperation, vol. 10, 2014, pp. 56-59

[3] S.J. Ma and L. Zheng, "Analysis on the motivation of China's direct investment in India," finance and economics research, vol. 12, 2009, pp.73-76.

[4] S.T. Hu, "Case study on risk prevention of investment in India by Chinese Iron and Steel Company," China Collective Economy, vol. 19, 2012, pp. 22-23.

[5] X.Y. Mei, "Analysis of international economic cooperation," Risk in Direct Investment in India, vol. 5, 2014, pp. 66-69.

[6] Z.D. Zhou, "Study on the risks and countermeasures of Chinese enterprises' foreign direct investment," North China Economic and Trade Cooperation, vol. 5, 2014, pp. 187-640.

[7] S.G. Han, "Study on the risk of overseas direct investment of Chinese enterprises," Jilin University Press, 2014.

[8] W.G. Li, "Analysis of foreign direct investment and its economic effects in India," Sichuan University, Press, 2006. 